\title{
Domestic Violence Against Woman: Its Relevance To A Gender-Sensitive Policy
}

\author{
Fentiny Nugroho ${ }^{1}$, B. Yuliarto Nugroho ${ }^{2}$, Laras Wijayanti ${ }^{3}$ \\ \{fentiny2015@gmail.com ${ }^{1}$,nugroho_yuliarto@yahoo.com²,laraswija@gmail.com\} \\ Dept. of Social Welfare, Faculty of Social and Political Sciences-Universitas Indonesia ${ }^{1}$, \\ Dept. of Business Administration, Faculty of Social and Political Sciences-Universitas \\ Indonesia $^{2}$
}

\begin{abstract}
Domestic violence was often called a hidden crime. This study aims to describe about causes of domestic violence against woman, to critically analyze them using a system and ecological perspective and to analyze its relevance to policy. The method used in this study was mainly literature critical analysis with a brief case. The incidence of domestic violence occured due to multiple factors: socio-economic , psychological and cultural factors. The social and cultural factors were closely related to gender issue. Generally people tended to deal with only the victims (women), but the problem was not resolved effectively. Based on the system and ecological perspective, not only the abused woman needed counseling, but also the perpetrator (her husband) because of his bad anger management and his violent childhood. Even their children needed counseling too.In this case there are some myths. A wife usually stayed even though she was always abused by her husband; the myth: she enjoyed it (a masochist). Actually she did not. This happened because she was economically dependent on her husband, she did not want her children to suffer, or because the husband asked for forgiveness. To cope with domestic violence more effectively, we needed both micro strategy (counseling) and public policy (a macro level) which is sensitive to gender issues. Finally, raising awareness of society about the domestic violence and future research about its impact on children are important.
\end{abstract}

Keywords: domestic violence, gender, policy, woman abuse.

\section{Introduction}

Women never ever have feeling that one day their marriage would be like in hell. The prospective husband who was gentle and loving can change to be a monster. The questions raise: why do they become wife batterers? How is the impact on their children?

Previous studies show that lack of consensus on issues of gender and culturally competent practices within the modalities present significant barriers to providing a holistic continuum of care for both perpetrators and victims of domestic violence [1]. Most interviewees grew up in families of origin in distress; most were abused physically and emotionally. Implications for intervention are suggested [2]. Intimate partner violence is a 
complex social problem rooted in structural gender inequality, but that affects individual women in different ways [3]. . The effect of intimate abuse on mental health, the data speak loudly to the power of partner abuse [4]. To deal with the problem, empowerment is important [5]. There are some of the systemic contradictions that appear to exist between the three areas of work on domestic violence, child protection and child contact, arguing that these can be perceived of as operating on separate 'planets', each with their own cultures, laws, policies and practices [6]. It appears that previous studies have not had adequate focus on multifaces of dometic violence. Therefore, this paper seeks to describe the complex factor of woman abuse case, which implies on the intervention

\section{Case Study (from Ciptomangunkusumo Hospital)}

An abused woman (client) left her hometown to work in Jakarta since 1999. In Jakarta the client had worked as a cake shop waiter in Jatinegara Market for 1 year, then became a domestic worker for about 2 months in the area around Jatinegara as well. When working as a domestic worker, the client is more acquainted with the street shoes named BL on the edge of Jatinegara Market, which sells in front of the cake shop. If she is told to go shopping to the market, she often passes by and stalls to the street vendors BL just says hello or jokes because while working as a domestic worker she feels bored and rarely gets out of the house because her employer's home environment does not really associate outside.

Occasionally she would chat with neighboring domestic workers. Several times she met BL, until one day BL said he wanted to marry her. Initially STN was doubtful because she felt BL's age was far away from her, which was about 15 years older with her. However, over time STN feels comfortable and because BL offers a contract for a house so STN thinks it is better to live outside and have a husband than to continue to be a domestic worker, and also her younger sibling in the village is already married.

After being planned with BL, she finally arrived at the time to tell her boss that she would get out of work and get married. BL also fulfilled his promise, he married STN by saying the marriage contract was witnessed by the cleric at the rented house that had been provided for her and after that she received a marriage book. STN feels happy because BL sincerely loves her. BL forbade STNs to work again, just living in a rented house with only 1 room, washing their clothes, and cleaning the house, she was also given enough money for enough snacks.

Several times a week, clients are invited to help sell by her husband. The client only has one fire stove, one small pot and one skillet which is placed near the bed, so she has more snacks at the beginning of her marriage. The client has imagined going home to Wonosobo with BL if there is money and the client does not feel ashamed of people in the village because she is married. The age of her husband far enough away from her is not a problem.In the midst of her 1-month-old marriage, the client asks her husband why he prefers more clients at home, even though the client wants to be invited to wait for the merchandise on the market. Her husband said that he had a wife but had no children, so he married the client because he wanted to have children.

Clients also feel disappointed and sad to hear that. But her husband said that he would divorce his wife once he had children with clients. In the third month, the client became pregnant and told her husband about this good news. After becoming pregnant, her husband said that she should not leave the house to be healthy until giving birth. The client refused but her husband was angry. This is the first time the client has seen her husband angry.Finally the 
client obeyed her husband's wishes. Since then the client has often been locked in her rented house and food for breakfast and lunch is bought by her husband. Whatever food she wants because she is pregnant is always bought by her husband, for example, the client wants grapes, brown bread, doger ice, and so on. The client's pregnancy went smoothly without any complaints, but the client found several times her husband came home late at night in a drunken state.

The client also claimed to have been beaten for asking for rent and pocket money. Her husband said he was penniless because there were not many merchandise bought and the client said she could not eat and had rented neighbor money. Hearing that BL was angry and forbade clients to owe their neighbors in shame. Since then, at the age of childbirth the client enters 6 months, BL more often comes home late at night drunk and sometimes while holding a bottle of liquor and goes home in a staggering condition early in the morning before dawn.

Until one ill-fated night for the client, because the client had not been given pocket money for a month, he already owed his neighbor and promised to pay it off tomorrow, then when BL returned home drunk, the client opened the door irritably, saying tomorrow he must be given money to pay debts. Apparently BL was emotional, and he hit the client several times.

The client also managed to dodge and fight again with BL.At this time BL was very angry, grabbed the hanging scissors and suddenly the client felt her eye ache and blood had poured from her left eye.

The client was confused and panicked, then grabbed the towel in the clothesline behind the house. Seeing the rented door has not been locked, the client comes out of the rented house, walks down the aisle while looking for a passing bajaj. The client then found the bajaj passing by and asked the bajajdriver to take her to the hospital Dr. Ciptomangunkusumo (RSCM).Inside the bajaj the client always holds a towel with her left hand covering her eyes. Approximately before dawn the client arrived at the RSCM ER. In ER the client realizes and is told by the nurse that her eyes are pierced by sharp objects (scissors), so that the action is immediately given.

On the way to the bajaj the client realized that all this time she had been lied to, her husband admitted that he did not have children with his first wife, but info from his neighbor that her husband had 3 children in the KampungMelayu area. He also saw her husband turn rough after she was pregnant. The next day the client met with Social Workers who were notified by the IGD section. Clients are found in the patient's care room. Clients are visited by Social Workers every day in turn.

\section{Causes of Domestic Violence}

The causes of wife abuse are complex. Social factors [7] consist of:

3.1 Social Sanction. It is a fact that social sanction influences violence against woman. For example, a husband slaps his wife is regarded as normal. Different from myths, there is a study shows that the higher education and income are, the higher rate of physical agression permitted between husband-wife.

3.2 Myths and streotype. Myths make women feel embarrased to ask for assistance and the others are reluctant to offer help. An example of myth: an abused woman still stay in her home beacuse "she likes it"; this myth causes people not to have any reason to help for someone who chooses to be treated that way (being abused). 
3.3 Economic factor. This factor causes the women to find difficult to escape away. In general, eventhough the women work, their salary is low. A study in America reveals that woman's salary is lower than man's salary [8]. So, if divorce, the women face economic problem because ex-husband does not always want to give financial support.

3.4 Role model based on sex. Apparently in society there are strong values that woman must be obedient, understand and always adjust to husband. Only if woman serves her husband well, she is viewed as beautiful by her husband and society. So, woman is valuable if she fully dedicates herself to husband and children.

In society, boys are adored more than girls. Boys are punished more badly and get more pressure. Consequently, boys tend to view girls as weak and not important. This view is "destructive". High expectation toward men who are appreciated if he has great acheievement and cannot show his emotion, that as a man must always win, finally causing stress to them. Many studies also demonstrate that men are more easily get heart attack and die at younger age.

Society also teaches that real men are never passive or dependent, always be dominant over women and never express their feeling directly, especially if this can negatively affect his domination. Therefore, there is possibility that a husband abusing his wife is not actually aware of his anger and frustration in himself, until he cannot stand the pressure. Then he does violence. Through this violent action, he does not perform his emotional response, instead, he maintain his superiority.

3.5 Men's insecurity about their worth as breadwinners, fathers and sexual partners

3.6 The use of alcohol and drugs. These cause people to be more temperamental and agressive.

3.7 Trigger factor. The incidence often occurs due to small things, for example, when the husband comes home, the children have not been bathed or he finds his meal is too salty.

In society there are some myths. Usually a wife does not leave her husband and children, although she is always abused by him; the myth is that she enjoys it (a masochist). Actually she does not. This happens because she is economically dependent on her husband, she does not want her children to suffer, or the husband asks for forgiveness. Moreover, battered women do not leave husband because " many are socialized to play a subordinate role, feel inadequate to live on their own, some believe that marriage is forever (their duty), a hope the husband will change, fear to leave that husband will retaliate with more severe beating, believe that occasioanl beatings are better than loneliness and insecurity connected with leaving, stigma associated with separation and divorce" [9]

Violence is a cycle which is called "cycle of violence". The violence begins with tense between spouse. Then the husband begins abuse his wife. Aftter this, he regrets and asks for forgiveness. The wife also feels that this happened because of her fault too. He is very kind to the wife; this is called "honeymoon". Later, the "honeymoon" efforts cease and tensions about work or family matters again begin. Husbands again batter their wives.

\section{Discussion}

The Ecological model views the individual as embedded in a family system,with all parts of the family relating to the larger social and political community, such as school and work and the larger social system. This social system consists of ideology, culture, gender, 
ethnic group, religion, and so on. All aspects of the social system are inter-related, creating a reciprocal influences on each other.[10] [11].

Based on description above, it is noted that the causes of woman abuse are multifaceted. The case is caused by many factors: family and larger system, like culture, social aspects, economic factor, and so on. Therefore, in dealing with the case, the approach should represent ecological approach. The services claimed by Zastrow [12] are system and ecological in nature. The services should be developed for battered women are shelter homes for battered women and their children in many communities, battered women receive counseling, assistance for battered women finding a job and legal help, batterer's group therapy, mariage counseling for both spouse, 24 hours hotlines that encourage potential spouse of abuser to call. Many people do not have knowledge of law on domestic violence, therefore it is important to have public information program announcing to women that they have legal rights not to be abused and they need to know resources to stop abuse. Furthermore, as her children are badly affected, they also need counseling, in the hope when they will marry in future, they would not repeat violence, especially a boy regard father as a role model.

In the USA, some states have domestic abuse law. Zastrow states : "the law require police to make an arrest if phisical abuse has occured and injury or threat of further harm may exist. Police face criminal or cilvil penalties under the law if they do not make mandated arrest". [13] Indonesia has law on domestic violence. Apparently, since this law is enforced, more and more people report the cases. However, the police should have knowledge of the law and be sensitive to gender issues. Otherwise, law enforcement will fail. Furthermore, Douglas proposes "a holistic approach to service delivery must be taken to ensure that women, who are victims of domestic violence, and their children are safely housed so that the threat of unnecessary child removal is reduced. Women require practical assistance including housing and income support, emotional support, and other forms of specialized assistance" [14].

\section{Conclusion}

This study finds that domestic violence case is multi-faceted. It is caused by many factors, including family and social system. This incorporates psychological, physical, cultural, social and economic dimensions. Therefore, it requires a comprehensive assessment, so the case can be analysed in great depthand the intervention plan can be formulated more accurately. The assessment for woman abuse case should consider many aspects, especially if the spouse want to maintain the family unity and society want to prevent the high rate of incidence. For this purpose, the ecological perspective is an appropriate paradigm. Using this perspective as a foundation for asessment, analysis and intervention, the case would be dealt with more comprehensively and effectively. It is important to note that the assessment and intervention forwoman abuse case should be able to identify problems, weaknesses, needs, and strengths of related systems for woman and family's well being. Importantly, although cases at micro level are crucial, it should not separated from macro level, namely policy and law. In dealing with the case, the policy which is sensitive to gender issues is very important. The policy should be formulated using case's insights. 


\section{References}

[1] Barner, J.R \& Carney, M.M : Interventions for Intimate Partner Violence, a Historical Review. J FamVol 26:235-244(2011).

[2] Buchbinder, E., \& Birnbaum, L: Strength Trapped Within Weakness/ Weakness Trapped Within Strength: The Influence of Family of Origin Experiences on the Lives of Abused Women. Violence Against Women, 16(6), 658-678 (2010).

[3] Cattaneo, L. B., \& Goodman, L. A :What is empowerment anyway? A model for domestic violence practice, research, and evaluation. Psychology of Violence, 5(1), 84-94(2015).

[4] Fleury-Steiner, R. E., Fleury-Steiner, B. D., \& Miller, S. L : More Than a Piece of Paper? Protection Orders as a Resource for Battered Women. Sociology Compass, 5(7), 512-524(2011).

[5] Hester, M :The Three Planet Model: Towards an Understanding of Contradictions in Approaches to Women and Children's Safety in Contexts of Domestic Violence. British Journal of Social Work, 41(5), 837-853. doi:10.1093/bjsw/bcr095. (2011).

[6] Johnson, M. P. Domestic Violence: It's Not About Gender-Or Is It?.Journal of Marriage and Family, 67(5), 1126-1130(2005).

[7] Hofeller, Kathleen H : Battered Women, Shattered Lives. California. RE Publihers (1987)

[8] Hofeller, Kathleen H : Battered Women, Shattered Lives. California. RE Publihers (1987)

[9] Hofeller, Kathleen H : Battered Women, Shattered Lives. California. RE Publihers (1987)

[10] Okun, Barbara F.. Effective helping: interviewing and counseling techniques. $6^{\text {th }}$. ed.:Brooks/Cole. USA (2002)

[11]Robbins, Susan P and Pranab Chatteriee: Contemporary Human Behavior Theory. Pearson. Boston (2006).

[12]Zastrow, Charles: Introduction to Social Work and Social Welfare. Brooks/Cole. Pacific Grove (1996)

[13]Zastrow, Charles: Introduction to Social Work and Social Welfare. Brooks/Cole. Pacific Grove (1996) Violence, and Child

[14] Douglas, Heather and Tamara Walsh: Mothers, Domestic Violence and Child Protection. Research Symposium. 16(5) 489-508 